\title{
Comparative Analysis of The Two Sites of Lahe (Caulerpa sp.) Growth for Determine The Range of Atmospheric, Physical and Chemical Water Conditions
}

Christophil Medellu ( $\square$ chmedellu@yahoo.com )

Manado State University https://orcid.org/0000-0003-2032-6748

Ni Wayan Suriani

Manado State University

Alfrits Komansilan

Manado State University

\section{Research}

Keywords: lahe (caulerpa sp.), ecological features, parameter, growth, productivity

Posted Date: May 8th, 2020

DOI: https://doi.org/10.21203/rs.3.rs-19439/v1

License: (c) (1) This work is licensed under a Creative Commons Attribution 4.0 International License.

Read Full License 


\section{Abstract \\ Background}

Ecological conditions determine the growth and productivity of lahe (Caulerpa Sp.). We conduct a comparative study of ecological conditions that affected differences in growth and productivity of lahe in two locations, in the Batunderang village area and the Lapango village area, Sangihe Regency. The ecological factors that we examined include atmospheric, chemical and physical factors. Atmospheric variables include radiation intensity, duration of irradiation, the air temperature above sea level. The physical and chemical parameters of water studied include current velocity, seawater temperature, salinity, current strength, $\mathrm{pH}$, dissolved oxygen, and nitrate concentrations.

\section{Results}

The indicator of lahe growth are: chain length, stem diameter, meristem diameter. The productivity indicator is the wet weight of the lahe harvested by farmers within 90 days. Comparative analysis between locations and measurement positions summarizes the range of ecological conditions for natural growth. The seabed for lahe is $0.8 \mathrm{~m}-1.4 \mathrm{~m}$ lower than the surface of a coral reef and is not exposed at the lowest tide. The air temperature range at position $20 \mathrm{~cm}$ above sea level is $25^{\circ} \mathrm{C}-31.6^{\circ} \mathrm{C}$, while the temperature of seawater varies between $25^{\circ} \mathrm{C}$ to $28.4^{\circ} \mathrm{C}$. Daily fluctuations in current velocity at high tides range from $0.09 \mathrm{~cm} / \mathrm{sec}$ to $2 \mathrm{~cm} / \mathrm{sec}$. The salinity range between $27.8 \mathrm{ppt}$ to $28.6 \mathrm{ppt}$. The $\mathrm{pH}$ range of seawater for natural growth is $7.6-8.12$, while the dissolved oxygen range is $6 \mathrm{ppm}$ to $6.25 \mathrm{ppm}$. Nitrate concentrations in lahe growth positions vary between $1.8 \mathrm{ppm}-1.96 \mathrm{ppm}$.

\section{Conclusion}

This ecological condition guarantees that the productivity of lahe varies between $20-30 \mathrm{~kg} / \mathrm{m}^{2}$ for a 90 day harvest period.

\section{Background}

Lahe is the local name of the green algae caulerpa sp. [1] which is consumed as fresh food by the Sangihe community. Lahe grows naturally in the coastal waters of the villages of Lapango and Batunderang, Sangihe Regency. The Sangihe community has not used it as a processed food product, or as an ingredient for medicines. Seaweed caulerpa $s p$. grow in the lower subtidal zone, attached to the sand substrate or broken rock or on mangrove roots or mangrove branches that are broken and stuck in the mud. The percentage of the existence of this algae is only around $13 \%$ of all types of algae that grow naturally [2]. Caulerpa lentillifera has advantages as a functional food because of its high nutritional composition [3]. Caulerpa sp extract has potential antioxidant compounds that capable to scavenging free radicals 1,1-diphenyl-2-pycryl hydrazil picrilhidrazine [4]. The isolation of bioactive metabolites from 
green algae is kahalide F, which is currently being studied for cancer treatment [5]. Green algae is a food ingredient that is very strong in vegetables causing cancer cell death [6].

Ecological conditions of the caulerpa sp. controlled by the interaction of biotic and abiotic elements [7]. Algal or seaweed forests experience various pressures that cause a decrease in abundance [8,9], and can even cause death. Survival, growth, and reproduction seaweed vary due to the influence of environmental factors such as temperature, desiccation, wave heights, nutrient supply via upwelling and run-off, $\mathrm{pH}$ and carbon dioxide concentration [10]. Global warming, increasing the concentration of carbon dioxide in the air and the sea, lowering pH and increasing the temperature of seawater on a global scale [11]. Despite global triggers, local stressors and regional variations have a more dominant influence on the dynamics of seaweed growth [12]. The influence of local environmental factors are interactive or related. Increasing the intensity of the radiation causes an increase in air temperature and water temperature. An increase in water temperature is associated with an increase in $\mathrm{pH}$, dissolved oxygen, and phytoplankton production [13]. The interaction of light and nutrition determines the carbon ratio that affects seaweed growth [14]. The penetration of light in water affects photosynthesis and seaweed growth [12,15]. Seaweed that is exposed and receives sunlight for a long time, can become dry and die [10].

The speed of ocean currents changes throughout the day following tides [1]. Tidal activity causes the seaweed area to open and can cause seaweed desiccation. Water flow also determines nutrient transport [16], water temperature dynamics [17], sediment load [18], and contaminants [19]. Carbon dioxide concentration in water is a limiting factor for seaweed growth [20]. Weather influences the growth rate of algae $k$. alvarezii. Nursidi et al [13] research results show that $k$. alvarezii growth is more significant in the rainy season than in the dry season. Conversely, In contrast, Msuya and Salum [21] concluded that $k$. alvarezii grow well in the dry season, but slowly in the rainy season. Local ecological characteristics are associated with abiotic and biotic interactions. Research on ecological features, and abiotic factors that control the growth of seaweed caulerpa $s p$. needed in evaluating the potential of caulerpa $s p$. and cultivation. We conduct research in two stages. The first stage is abiotic factor research, and from the results of biotic factor research, we developed a study of the interaction of abiotic factors with biotics in tidal waters. Abiotic factors studied include the intensity and duration of direct irradiation, exposure duration, air temperature, water temperature, current speed, salinity, $\mathrm{pH}$, dissolved oxygen and nitrate concentration in water. This article describes part of the results of the study, to compare ecological features, the magnitude of atmospheric, chemical and physical variables, productivity and growth of caulerpa sp., And the daily dynamics of currents, air temperature, and water temperature as controlling factors.

\section{Method}

In this section and subsequently, the author uses the local term "lahe" for caulerpa $s p$. This article presents the results of research conducted from September 13 to September 16, 2019. In this period there was a full moon on September 14, 2019. The study was conducted around the full moon to obtain the data of chemical and physical water variables which are assumed to fluctuate maximally following the 
tides. The study was conducted at two sites of lahe growth, in the area of South Manganitu District, Sangihe Regency. The results of a survey conducted in 2018, concluded that these two locations are areas of natural growth of lahe Productivity of lahe are different between the two locations. Measurement and sampling of water and lahe at each location were carried out in two positions. Position- 1 in the area of growth of lahe around the roots of mangroves, and position-2 on coral reefs which are the substrate of lahe. The research team consisted of two groups, each consisting of one lecturer, three students, and one guide. The guide is a seaweed farmer at the study site, whose task is to take water and lahe samples, to identify the measurement positions, and provide information about the productivity and growth of lahe. On the first day, the team made observations, measurements and recorded ecological feature data, to identify the measurement and sampling positions. Measurement, sampling, and analysis of samples were carried out on the second and third days. The fourth day was used for data validation and additional measurements needed.

The atmospheric factors measured include the intensity of the light, the duration of the exposure, and the air temperature, which were carried out at position-1 and position-2, for location-1 and location-2 respectively. Measurement of light intensity is done from 06:00 to 18:00, with a measurement interval of two hours. Measurement of air temperature is carried out for 24 hours, with a measurement interval of two hours. Measurement of light intensity and air temperature is done at a distance of $20 \mathrm{~cm}$ above sea level, to get data of the thermal interaction between air and water. Physical variables measured and analyzed are water depth, water temperature, and current velocity. The depth of the water and current velocity changes according to the tide. These two variables are measured for one tidal period, from 6:00 to 18:00. Seawater temperature is affected by irradiation, absorption, storage and thermal emissions by the mass of water, whose change period is 24 hours $[22,23]$. Seawater temperature is measured from 06:00 to 06:00 the next day, with a measurement interval of two hours. Water temperature measurements are carried out at a distance of $10-20 \mathrm{~cm}$ above the lahe. At low tides, water temperature measurements are only carried out at position- 1 that is still flooded. Position- 2 is open at low tides and no measurements are taken. Chemical variables studied include salinity, $\mathrm{pH}$, dissolved oxygen and nitrate concentrations. Measurement of chemical variables is carried out on water samples, taken from each position and measurement location. Samples were taken for four variations of tides, namely when the tides are highest (around 06:00), when the sea level moves down from the highest to the lowest tides (09:0009.30), at the lowest tides (12:30 - 13: 00), and when the water level moves up (15:00-15:30). This water sampling is based on the assumption of nutrient transport and dissolved chemicals that are affected by the movement of water during tides. Water samples for measurement of chemical parameters were taken at a height of $10-20 \mathrm{~cm}$ above lahe. At the lowest tide, measurements of salinity and $\mathrm{pH}$ at the exposed positions are carried out directly on the culerpa sp. tissue, while dissolved oxygen and nitrate concentrations are not measured.

\section{Results And Discussion}

This section describes the comparison of the ecological features of the two locations to get an overview of potential locations for lahe growth. Next, we describe the comparison of atmospheric, physical and 
chemical factors of water, and their effects on growth and productivity between positions in the two study sites. Daily dynamics of currents, air temperature and water temperature as factors controlling the lahe ecosystem, presented and discussed in the last section.

Comparison of ecological features of the two growth sites of lahe.

Table-1 presents a comparison of ecological features between the two locations of lahe growth. The tidal plain of the two locations shows similarity in ecological conditions such as the presence of coral reefs, fringing reefs, and associated plants. The presence or absence of the river causes some differences in the two locations. Freshwater and mud supply is higher at location-1 because there is a river flow. At location2 there is no river flow. This difference causes differences in the substrate, type, and density of mangroves [22], and so on affect the growth of lahe. Lahe growth area around mangrove roots is deeper in location- 1 because of the freshwater flow from the river. Lahe in position- 1 for location-1 and location-2 are not exposed and remain flooded during the lowest tide. The irradiation duration at location- 1 is less compared to location-2.

Table-1. Comparison of ecological features of location-1 and location-2

\section{Location-1}

Fresh water flow, river estuary, $80 \mathrm{~m}$ from the location

High mud sedimentation during floods, low during drought.

Dense coral reef and good condition

Fringe reef: rare, good condition

mangrove: dense, predominantly rizophora, width: $70-80 \mathrm{~m}$

Association: seagrass, good condition

The caulerpa sp area is not exposed at low tides

Seabed: thick mud, a little sand

Coastal orientation: $38^{0}$ west-south $-38^{0}$ east-north

Direct radiation: 08:00-18:00, in the morning, protected by hills

\section{Location-2}

There is no river flow, fresh water seepage from gravel and sand gaps

Mud supply is low, only through surface abrasion,

Dense coral reef and good condition

Fringe reef: rare, good condition

mangrove dominated avicenia, rarely, width: 20$30 \mathrm{~m}$

Association: seagrass, rarely

Most areas are exposed for 2 hours when tides are lowest

seabed: sandy mud

Coastal orientation: $8^{0}$ west-south $-8^{0}$ eastnorth

Direct irradiation: 6:00-18:00

Comparison of atmospheric and chemical-physical water conditions

Table-2. Comparison of atmospheric, chemical and physical variables and parameters 
Table 2

shows the difference between the atmospheric, physical and chemical parameters of the two study sites. The two locations show different irradiation durations due to the orientation of the beach to the sun's path (Table-1). In the absence of rain, the maximum air temperature measured at a height of $20 \mathrm{~cm}$ above sea level at position-2 is higher than position-1. This maximum air temperature is reached around 13:00. The water temperature is also higher at position-2 and is reached around the same time as the air temperature. Water temperature and air temperature are interactive in flowing thermal energy. In position 1, both air temperature and water temperature are lower than position 2, due to the supply of freshwater whose temperature is lower. The maximum water temperature in position-1 is lower than the range of water temperatures obtained by Nursidi et al [13], which is between $29-33^{\circ} \mathrm{C}$. The seabed at location-1 position-1 is deeper than other positions, because of the river channel. Lahe in position-1, not exposed to sunlight when the tide is low. In position 2, lahe exposed at low tides, due to the high surface of coral reefs. Current velocity changes temporally following tides. The maximum sea current velocity in position-1 is lower than position - 2. The maximum current velocity at position-1 is slightly higher than the results of research by Nursidi et al [13], but it is still within reasonable criteria for seaweed growth. Water chemistry data show the difference between position-1 and position-2 at location-1 and location-2. Maximum salinity is around the ideal of salinity for seaweed growth [24] which is $30 \mathrm{ppt}$. The range of salinity obtained from the research, is almost the same as the range of salinity for optimal growth of Caulerpa lentillifera studied by Deraxbudsarakom et al [25] which is 25-30 psu. Such is the case with pH, dissolved oxygen content, and nitrate concentrations in water. Water chemical parameters measured at four different times according to tidal conditions do not show significant differences.

\begin{tabular}{|lllll|}
\hline Parameter & Location-1 & \multicolumn{3}{c|}{ Location-2 } \\
\cline { 2 - 5 } & position-1 & position-2 & position-1 & position-2 \\
\hline Duration of direct irradiation (hour) & 10 & 11 & 12 & 12 \\
\hline Maximum air temperature (no raindrop) $\left({ }^{0} \mathrm{C}\right)$ & 31.6 & 32.1 & 31.8 & 32 \\
\hline Maximum depth $(\mathrm{m})$ & 6.4 & 5.0 & 56 & 4.8 \\
\hline Exposure duration at lowest tide (hour) & 0 & 1.8 & 0 & 1.7 \\
\hline Maximum current velocity (cm/det) & 1.95 & 3.52 & 2.01 & 3.50 \\
\hline Maximum water temperature $\left({ }^{0} \mathrm{C}\right)$ & 28.4 & 31.6 & 28.4 & 31.7 \\
\hline Maximum salinity (ppt) & 28.2 & 30.2 & 28.6 & 30.4 \\
\hline Maximum pH & 8.12 & 7.70 & 8.00 & 7.66 \\
\hline Dissolved oxygen $(\mathrm{ppm})$ & 6.25 & 6.12 & 6.18 & 6.10 \\
\hline Nitrate concentrations $(\mathrm{ppm})$ & 1.95 & 1.82 & 1.96 & 1.82 \\
\hline
\end{tabular}

Comparison of growth and productivity of lahe

Table-3. Conditions of growth and productivity of lahe 
Table 3

shows the productivity in position 1 , location-1 is higher than in location 2 , position-1. In position-2 for location-1 and location-2, farmers do not harvest because the growth is very slow.

\begin{tabular}{|lllll|}
\hline Productivity and growth of lahe & \multicolumn{2}{c}{ Location-1 } & \multicolumn{3}{c|}{ Location-2 } \\
\cline { 2 - 5 } & position-1 & Position-2 & position-1 & Position-2 \\
\hline Harvest period (days) & 90 & 0 & 90 & 0 \\
\hline Wet weight/area of harvest $\left(\mathrm{kg} / \mathrm{m}^{2}\right)$ & $25-30$ & 0 & $20-30$ & 0 \\
\hline Chain length at harvest $(\mathrm{cm})$ & $240-300$ & $50-54$ & $180-250$ & $48-54$ \\
\hline Thallus diameter $(\mathrm{mm})$ & $2.6-3,0$ & $1.2-2.2$ & $2.2-2.8$ & $1.2-1.9$ \\
\hline Meristem diameter $(\mathrm{mm})$ & $3.0-3.3$ & $2.8-3.2$ & $2.8-3.2$ & $2.6-3.0$ \\
\hline density in average $(\mathrm{gr} / \mathrm{ml})$ & 0.56 & 0.70 & 0.56 & 0.71 \\
\hline
\end{tabular}

In position 2, the entire lahe chain is attached to the reef. At position-1, location-1, and location-2, the lahe chain is floating, only the base is attached to the substrate in the form of mangrove roots, dead coral or fringe reef. The diameter of the thallus and meristem at location-1, position-1 is greater than in other positions but has a lower density compared to position-2 at location-1 and location-2. Lahe in position-2, open to irradiation for about one and a half to two hours during the lowest tide. The color of lahe in position 2 is greener and brighter than position 1. Lahe which is attached to coral has a higher density compared to lahe that grows around mangrove roots [1].

Daily dynamics of current velocity

Figure-1 and Figure-2 show the daily dynamics of ocean current velocity at location- 1 and location-2. The daily change in current velocity for position- 1 and position- 2 has the same pattern. The daily maximum of current velocity for position-1, location-1 is $1.95 \mathrm{~cm} / \mathrm{sec}$, which occurs around 09:00. At the same time, the current velocity at position 1 location 2 reached the highest magnitude of $2.01 \mathrm{~cm} / \mathrm{sec}$. At the lowest tide position or around 12:00 - 13:00, the current velocity in position-1 location-1 is $0.22 \mathrm{~cm} / \mathrm{sec}$, slightly higher than the current velocity in position-1, location-2, which is $0,1 \mathrm{~cm} / \mathrm{sec}$. This is due to the flow of water from rivers. Low current velocity for all locations and positions also occurs at the highest tide, which is around 06:00 and 18:00. The current velocity in the lahe growth area or position-1 is lower than in position-2. Fluctuations of current velocity at position-1 are ideal for seaweed growth, such as the research results by Nursidi et al [13], which is $0.08-0.33 \mathrm{~cm} / \mathrm{sec}$. Comparison of the daily dynamics of current velocity at position 1 and position 2 for both locations, gives the conclusion that coral reefs can reduce the current velocity caused by tides

Daily dynamics of air temperature and seawater temperature 
Figure-1 and Figure-2 respectively show daily changes in air temperature and seawater temperature in position-1, location-1 and position-1, location-2. The time enumeration data in abscissa of Figure-1 and Figure-2 is associated with the real-time measurement. Enumerator 1 is associated with 06:00 a.m. Enumerator 2 is associated with 07:00 a.m. etc. The highest temperature of seawater at a distance of 10 $\mathrm{cm}-20 \mathrm{~cm}$ above lahe, is the same for location- 1 and location- 2 that is $28.4^{\circ} \mathrm{C}$. The data in Table- 1 shows that the maximum temperature at position-2 is higher than position-1. The lower water temperature at position-1 than position- 2 is caused by a supply of freshwater that has a low temperature. The range of daily changes in water temperature at the productive growth position or position- 1 is $24.6-28.4{ }^{\circ} \mathrm{C}$, lower than the ideal water temperature range for the growth of Kappaphycus alvarezii obtained by Nursidi et al [13], ie $29-33^{\circ} \mathrm{C}$. The highest temperature occurs around 13:00. The dynamics of air temperature and water temperature show thermal interactions in the upper layers of seawater $[22,26,27]$. The range of daily air temperature changes of natural growth of lahe is $25-31.6^{\circ} \mathrm{C}$, slightly higher than the ideal air temperature range for the growth of caulerpa lentillifera, which is $25-30^{\circ} \mathrm{C}$ [28].

\section{Conclusion}

Comparative analysis of ecological features, variations in atmospheric, chemical and physical factors, yields a reference to natural growth requirements. Ecological conditions that can be used as indicators of the presence of lahe or lahe cultivation potential are the presence of coral reefs, freshwater supply from rivers or seeps from rock or sand, and tidal plains that are lower than the surface of coral reefs. At the study site, the tidal plain is $0.8 \mathrm{~m}-1.4 \mathrm{~m}$ lower than the coral reef and is not exposed at the lowest tide. The existence of coral reefs controls the current velocity in the tidal plain so that the lahe can grow to form long chains. Daily fluctuations in current velocity at high tides range from $0.09 \mathrm{~cm} / \mathrm{sec}$ to $2 \mathrm{~cm} / \mathrm{sec}$. Freshwater supply guarantees salinity in the range: $27.8 \mathrm{ppt}-28.6 \mathrm{ppt}$, and controls variations of water temperature between $25^{\circ} \mathrm{C}$ to $28.4^{\circ} \mathrm{C}$. Daily air temperatures at a position $20 \mathrm{~cm}$ above sea level fluctuate between $25^{\circ} \mathrm{C}$ to $31.6^{\circ} \mathrm{C}$. The supply of freshwater also carries nutrients and dissolved chemicals in an ideal size. The $\mathrm{pH}$ range of seawater for natural growth is $7.6-8.12$, while the dissolved oxygen range is $6 \mathrm{ppm}$ to $6.25 \mathrm{ppm}$. Nitrate concentrations in lahe growth positions vary between $1.8 \mathrm{ppm}-1.96 \mathrm{ppm}$. This ecological condition guarantees that the productivity of lahe varies between $20-30 \mathrm{~kg} / \mathrm{m} 2$ for a 90 day harvest period.

\section{Declarations}

Availability of data and materials

Not applicable

Competing interests

Not applicable 
Funding

Not applicable

Authors' contributions

Not applicable

Acknowledgements

The author would like to thank the Sangihe Regional Government for permission to conduct research. Acknowledgments were conveyed to the community at two locations for their support of implementation and providing related information. Thank you and high appreciation to the team of lecturers and students of physics and chemistry study programs of Manado State University, who took measurements at the site.

The authors would like to thank the anonymous reviewers and editorial staff for their comments which greatly improved this manuscript.

Authors' information

Affiliations:

Faculty of Natural Science and Mathematics, Manado State University, Tondano City, North Sulawesi, Indonesia

Christophil S. Medellu, Ni Wayan Suriani' and Alfrits Komansilan

\section{References}

[1] Medellu Ch.S., Ni Wayan Suriani N.W., and Komansilan A. 2019. Physical and chemical water conditions in and around the area of seaweed "Lahe" (Caulerpa Sp.) growth. J. Phys.: Conf. Ser. 1317 012048. doi:10.1088/1742-6596/1317/1/012048

[2] de Oliveira A.L.L., de Felício R., and Debonsi, H.M. 2012. Marine natural products: chemical and biological potential of seaweeds and their endophytic fungi, J. Pharmacogn. 22(4): 906 - 920.

[3] Nofiani R., Hertanto S., Zaharah T.A., and Gafur S. 2018. Proximate Compositions and Biological Activities of Caulerpa lentillifera. Molekul, 1(3): 141 - 147. doi: 10.20884/1.jm.2018.13.2.441.

[4] Noor N.M. and Nursandi J. 2014. Chemical Characteristics of Local Seaweed (Caulerpa sp.) And Its Potential as a Source of Antioxidants. Proceedings of the National Seminar on Agricultural Technology Development in Lampung State Polytechnic 24 May 2014 ISBN 978-602-70530-0-7 pages 577-584. 
[5] Folmer F, aspars M, Dicato M, and Diederich M. 2010. Photosynthetic marine organisms as a source of anticancer compounds. Phytochem Rev 9: 557-579.

[6] Fini L., Hotchkiss E., and Fogliano V. 2008. Chemopreventive properties of pinoresinol-rich olive oil involve a selective activation of the ATM-p53 cascade in colon cancer cell lines. Carcinogenesis, 29(1): $139-146$

[7] Thurber A.R., Sweetman A.K., Narayanaswamy B.E, Jones D.O.B, Ingels J., and Hansman R.L. 2014. Ecosystem functions and services provided by the deep sea. Biogeosciences, 11: 3941-3963. www.biogeosciences.net/11/3941/2014/ doi:10.5194/bg-11-3941-2014

[8] Mineur F., et al. 2015. European seaweeds under pressure: consequences for communities and ecosystem functioning. J. Sea Res, 98: 91-108.

[9] Coleman M. A., Kelaher B. P., Steinberg P. D., and Millar A. J. 2008. Absence of a large brown macroalga on urbanized rocky reefs around Sydney, Australia, and evidence for historical decline. J. Phycol, 44: 897-901.

[10] Sunny A.R. 2017. A review on effect of global climate change on seaweed and seagrass. International Journal of Fisheries and Aquatic Studies, 5(6): 19-22. E-ISSN: 2347-5129 P-ISSN: 23940506

[11] Harley Ch.D.G, Anderson K.M., Demes K.W., Jorve J.P., Kordas R.L., and Coyle Th.A. 2012. Effects of climate change on global seawedd communities. J. Phycol. 48:1064-1078. DOI: 10.1111/j.15298817.2012.01224.x.

[12] Krumhans K.A., et al. 2017. Global patterns of kelp forest change over the past half-century. Proc. Natl. Acad. Sci. USA 113, 13785-13790.

[13] Nursidi, Ali S.A., Anshary H., and Tahya A.M. 2017. Environmental parameters and specific growth of Kappaphycus alvarezii in Saugi Island, South Sulawesi Province, Indonesia. AACL - International Journal of the Bioflux Society: 10(04);698-702. ISSN 1844-9166 (online), ISSN 1844-8143 (print). http://www.bioflux.com.ro/aacl

[14] Juneja A., Ceballos R.M., and Murthy G.S. 2013. Effects of Environmental Factors and Nutrient Availability on the Biochemical Composition of Algae for Biofuels Production. Energies 6: 4607-4638; doi:10.3390/en6094607

[15] Marinho-Soriano E., Nunes S.O., Carneiro M.A.A., and Pereira D.C. 2009. Nutrients removal from aquaculture wastewater using the macroalgae Gracilaria birdiae. Biomass and Bioenergy. 33: 327-331

[16] Mangialajo L., Chiantore M., and Cattaneo-Vietti R. 2008. Loss of fucoid algae along a gradient of urbanization, and structure of benthic assemblages. Mar. Ecol. Prog. Ser. 358: 63-74. 
[17] Schiel D.R., Steinbeck J.R., and Foster M.S. 2004. Ten years of induced ocean warming causes comprehensive changes in marine benthic communities. Ecology 85: 1833-1839

[18] Eriksson B.K., Johansson G., and Snoeijs P. 2002. Long-term changes in the macroalgal vegetation of the inner Gullmar fjord, swedish Skagerrak coast. J. Phycol. 38: 284-296.

[19] Sales M., Cebrian E., Tomas F., and Ballesteros E. 2011. Pollution impacts and recovery potential in three species of the genus Cystoseira (Fucales, Heterokontophyta). Estuar. Coast. Shelf Sci, 92: 347-357.

[20] Kroeker K.J., Kordas R.L., Crim R.N., and Singh G.G. 2010. Meta-analysis reveals negative yet variable effects of ocean acidification on marine organisms. Ecol. Lett. 13: 1419-34.

[21] Msuya F.E., Salum D. 2007. Effect of cultivation duration, seasonality, nutrients, air temperature and rainfall on carrageenan properties and substrata studies of the seaweeds Kappaphycus alvarezii and Eucheuma denticulatum in Zanzibar, Tanzania. Technical report WIOMSA-MARG I No. 2007 - 06, (www.wiomsa.org)

[22] Medellu Ch.S. 2012. Mathematical modeling of microclimate diurnal gradient in mangrove Dissertation- Brawijaya, University, Malang, Indonesia

[23] Medellu Ch.S. 2013. The area and index of diurnal dynamic of microclimate gradient as a mangrove - environment interaction parameter. Journal of Natural Sciences Research, 3(14): 68-77. ISSN 22243186 (Paper) ISSN 2225-0921 (Online)

[24] Ding L., Ma Y., Huang B., and Chen S. 2013. Effects of Seawater Salinity and Temperature on Growth and Pigment Contents in Hypnea cervicornis J. Agardh (Gigartinales, Rhodophyta). BioMed Research Internationa/ Vol. 2013, Article ID 594308, 10 pages http://dx.doi.org/10.1155/2013/594308

[25] Deraxbudsarakom S, Songsangjinda P, Chiayvareesajja S, Tuntichodok P, Pariyawathee S (2003) Optimum condition of environmental factors for growth of sea grape (Caulerpa lentillifera: J. Agardh). Warasan Kanpramong (Thai Fisheries Gazette), AGRIS records, http://agris. fao.org/aos/records/TH2005000960

[26] Ward B., Wanninkhof R., McGillis W.R., Jessup A.T., DeGrandpre M.D., Hare J.E., and Edson J.B. 2004. Biases in the air-sea flux of $\mathrm{CO} 2$ resulting from ocean surface temperature gradients. J. Geophys. Res., 109, C08S08, doi:10.1029/2003JC001800.

[27] Jamshidi S., Abu Bakar N. B., and Yousefi M. 2010. Concentration of chlorophyll-a in the coastal waters of Rudsar. Research Journal Environmental Sciences, 10: 132-138.

[28] Guo H., Yao J., Sun Z., and Duan D., 2014. Effect of temperature, irradiance on the growth of the green alga Caulerpa lentillifera (Bryopsidophyceae, Chlorophyta). Journal of Applied Phycology 27(2): 879-885. ISSN 0921-8971. DOI: 10.1007/s10811-014-0358-7 
Figures

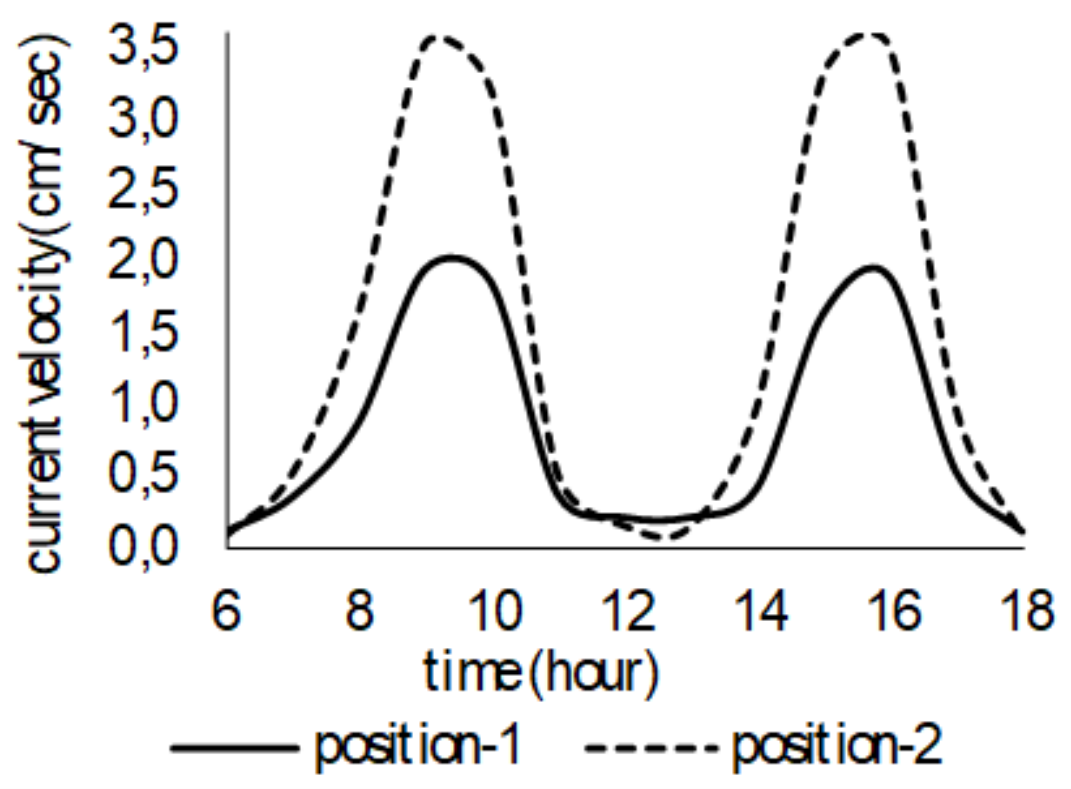

Figure 1

Daily dynamic of current

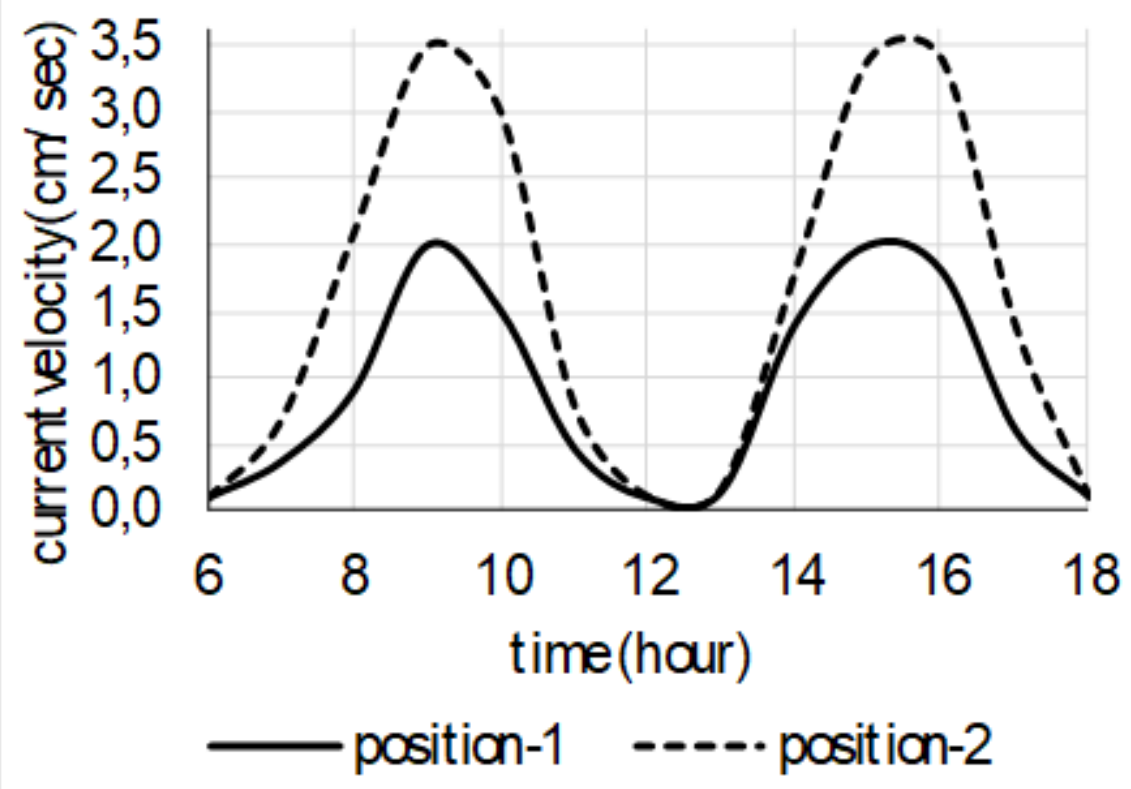

Figure 2

Daily dynamic of current velocity in location-2 


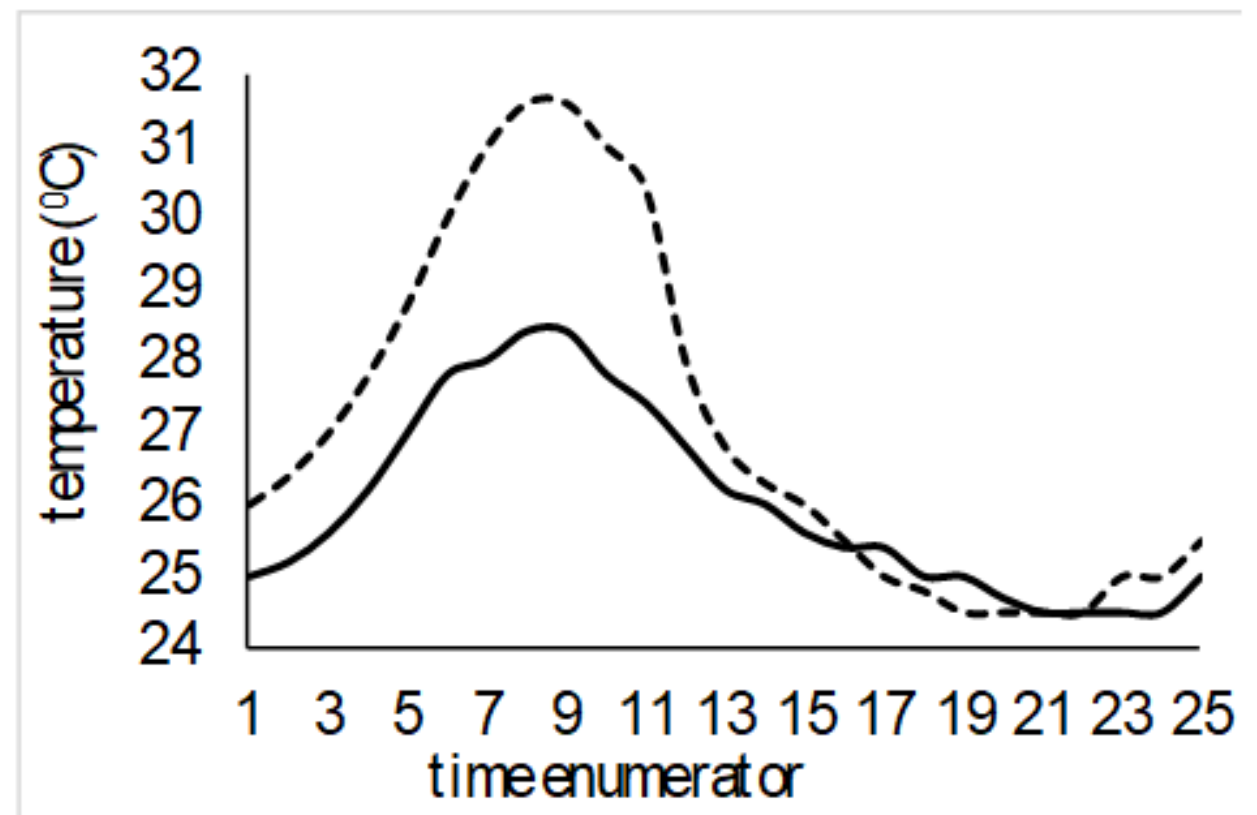

-----a air temperature —— water temperature

Figure 3

Daily dynamic of air and water temperature, location-1, position-1

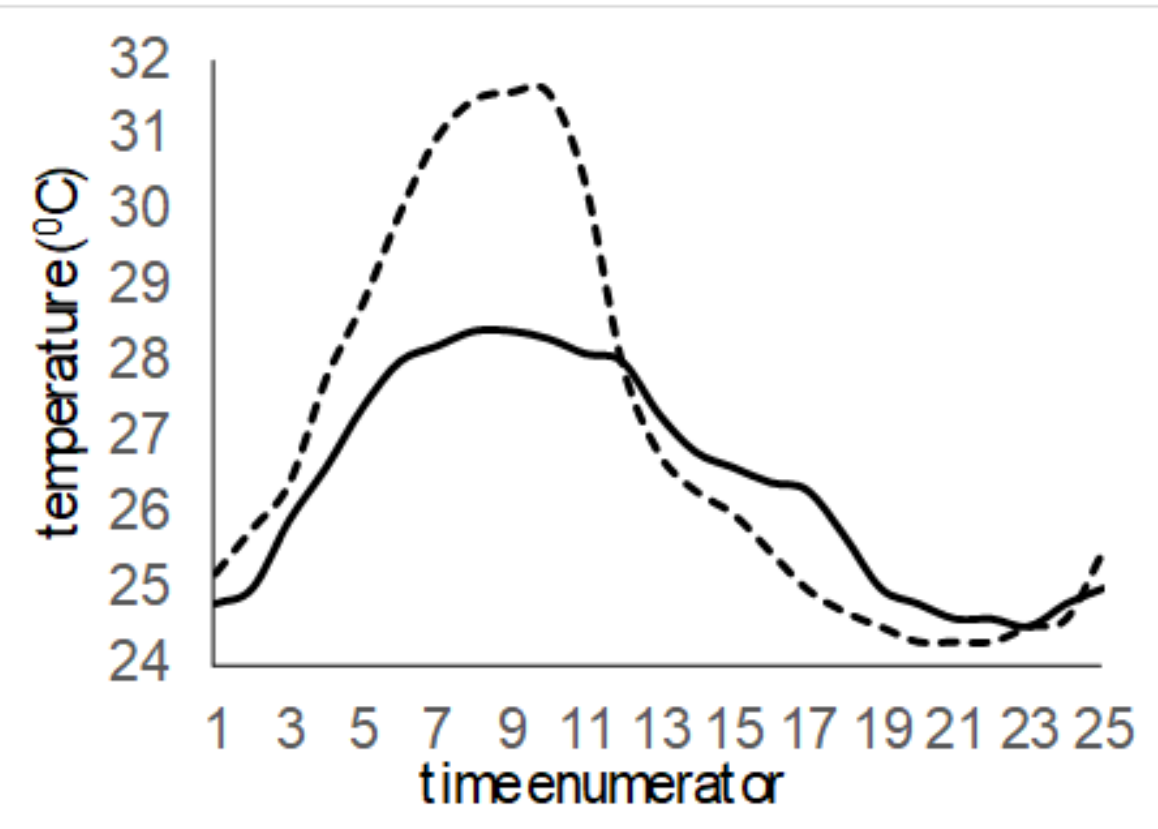

----- air temperature —— water temperature

Figure 4

Daily dynamic of air and water temperature, location-2, position-1 